\title{
IMPORTANCE OF CANNABINOIDS IN THE FUNCTIONING OF THE CENTRAL NERVOUS SYSTEM
}

\section{ZNACZENIE KANNABINOIDÓW W FUNKCJONOWANIU OŚRODKOWEGO UKŁADU NERWOWEGO}

\author{
Paula Wróblewska-Łuczka ${ }^{1(\mathrm{~B}, \mathrm{C}, \mathrm{D}, \mathrm{E}, \mathrm{F})}$, Magdalena Florek-Łuszczki ${ }^{2(\mathrm{~B}, \mathrm{D}, \mathrm{E}, \mathrm{F})}$, \\ Jarogniew J. Łuszczki ${ }^{1(\mathrm{~A}, \mathrm{E}, \mathrm{F}, \mathrm{G})}$ \\ ${ }^{1}$ Department of Pathophysiology, Medical University in Lublin, Poland \\ ${ }^{2}$ Department of Medical Anthropology, Institute of Rural Health in Lublin, Poland
}

Authors' contribution Wkład autorów: A. Study design/planning zaplanowanie badań B. Data collection/entry zebranie danych C. Data analysis/statistics dane - analiza i statystyki D. Data interpretation interpretacja danych E. Preparation of manuscript przygotowanie artykułu F. Literature analysis/search wyszukiwanie i analiza literatury G. Funds collection zebranie funduszy

Tables: 0

Figures: 0

References: 68

Submitted: 2017 Nov 30

Accepted: 2018 Apr 21

\section{Summary}

At present, there is a great emphasis of public opinion on the legalisation of medical marijuana, i.e. the top parts of the cannabis plants rich in tetrahydrocannabinol (THC). Nevertheless, in the cannabis plants, there are many various cannabinoids, including cannabidiol (CBD). Scientific reports to-date indicate the possibility for using pharmacologically active cannabinoids in the treatment of such diseases/symptoms as: anorexia, vomiting, neuropathic pain, inflammatory diseases, multiple sclerosis, degenerative diseases of the central nervous system (Parkinson's disease, Huntington's disease, Alzheimer's disease, Tourette's syndrome), epilepsy, schizophrenia, and obesity. The article presents up-to-date information on the results of experimental studies concerning the effectiveness of cannabinoids, with particular consideration of diseases related with the central nervous system, including epilepsy, neuropathic pain, mental disorders, as well as obesity and anorexia.

Keywords: cannabinoids, central nervous system, brain diseases

\section{Streszczenie}

Aktualnie obserwuje sie duży nacisk opinii społecznej na legalizacje medycznej marihuany, czyli szczytowych części roślin konopi indyjskich bogatych $\mathrm{w}$ tetrahydrokannabinol (THC). Tymczasem, w konopiach jest wiele różnych kannabinoidów, między innymi kannabidiol (CBD). Aktualne doniesienia naukowe wskazuja na możliwość wykorzystania farmakologicznej aktywności kannabinoidów w obszarze leczenia takich chorób/ objawów jak: anoreksja, wymioty, ból neurogenny, choroby zapalne, stwardnienie rozsiane, choroby degeneracyjne ośrodkowego układu nerwowego (choroba Parkinsona, Huntingtona, Alzheimera oraz zespół Tourette’a), padaczka, schizofrenia, otyłość. W pracy przedstawiono aktualne informacje na temat wyników prowadzonych dotychczas badań nad skutecznością kannabinoidów, ze szczególnym uwzględnieniem chorób związanych z ośrodkowym układem nerwowym, w tym: padaczką, bólem neuropatycznym, chorobami psychicznymi oraz otyłością i anoreksją.

Słowa kluczowe: kannabinoidy, ośrodkowy układ nerwowy, choroby mózgu

\section{Introduction}

In the Cannabis sativa plants there occur more than 400 various substances belonging to more than a dozen chemical groups: carbohydrates, terpenes, fatty acids, steroids, heterocyclic compounds containing nitrogen, and cannabinoids, i.e. tricyclic benzopyran derivatives containing 21 carbon atoms.

Cannabinoids are a group of more than 100 organic compounds exerting an effect on cannabinoid receptors (CB). For the first time, these compounds were isolated from the herbaceous plant in the Cannabis genus. At present, this group includes cannabinoids known as phytocannabinoids (including $\Delta 9$-tetrahydroxycannabidiol (THC), $\Delta 8$-THC, tetrahydrocannabivarin, cannabinol, cannabidiolic acid, cannabidiol, cannabigerol, and cannabichromene), cannabinoids naturally occurring in plants and animals organisms, including humans so-called endocannabinoids (i.e., N-arachidonoylethanolamine AEA = anandamide, 2-arachidonyloglycerol = 2-AG), and synthetic cannabinoids made in laboratories (including, marinol, nabilone, and rimonabant applied in medical treatment) [1].

Wróblewska-Łuczka P, Florek-Łuszczki M, Łuszczki JJ. Importance of cannabinoids in the functioning of the central nervous system. Health Prob Civil. 2018; 12(3): 223-230. https://doi.org/10.5114/hpc.2018.75688

Address for correspondence / Adres korespondencyjny: Jarogniew J. Łuszczki, Department of Pathophysiology, Medical University in Lublin, Jaczewskiego 8 20-090 Lublin, Poland, e-mail: jarogniew.luszczki@umlub.pl, phone: +48 814486500

Copyright: (C) Pope John Paul II State School of Higher Education in Biała Podlaska, Paula Wróblewska-Łuczka, Magdalena Florek-Łuszczki, Jarogniew J. Łuszczki. This is an Open Access journal, all articles are distributed under the terms of the Creative Commons Attribution-NonCommercial-ShareAlike 4.0 International (CC BY-NC-SA 4.0) License (http://creativecommons.org/licenses/by-nc-sa/4.0/), allowing third parties to copy and redistribute the material in any medium or format and to remix, transform, and build upon the material, provided the original work is properly cited and states its license. 
The content of cannabinoids in the plant varies according to the phase of the life cycle. In the vegetative phase dominate: cannabinol (CBN), cannabidiolic acid (CBDA), and tetrahydroxycannabidiolic acid (THCA). In the vegetative phase, in the flowering period, THC prevails, which is converted into cannabidiol (CBD) and cannabigerol (CBG) [2].

Natural cannabinoids are chemical compounds which show pharmacological activity [3]. THC is famous for psychoactive properties [4], while CBD is not psychoactive; however, shows anti-inflammatory properties, protects neurons against damage or degeneration, decreases anxiety, alleviates drug hunger, and has antipsychotic properties. Current scientific reports indicate the possibility of use of pharmacologically active cannabinoids in the treatment of such diseases/symptoms as anorexia, vomiting, neuropathic pain, inflammatory diseases, multiple sclerosis, degenerative diseases of the central nervous system (Parkinson's disease, Huntington's disease, Tourette's syndrome, Alzheimer's disease), epilepsy, schizophrenia, cancer, obesity, and selected metabolic diseases $[5,6]$.

\section{Aim of the work}

The following work aims to present the potential of cannabinoids in the treatment of diseases associated with the central nervous system.

\section{Cannabinoid receptors}

Until today, the presence of two sub-types of cannabinoid receptors (CB1 and CB2) has been confirmed, which belong to the group of metabotropic receptors linked with G protein [7].

The studies conducted to-date allowed determination of the structure of CB receptors, their localisation and changes in pharmacological effects related to their selectivity and affinity. Acting on the CB1 receptor (constructed of 472 amino acids, 7 transmembrane domains) is combined with the multi-directional activation of metabolic paths. These receptors are located presynaptically on the surface of the neurons of the central and peripheral nervous system, adipose tissue, gastrointestinal tract, muscles, heart, lungs, liver, kidneys, testicles, ovaries, prostate, as well as cells of the immune system and in the placenta [8,9]. Expression of these receptors was also confirmed in the eye, astrocytes, glial cells, and in the anterior lobe of the pituitary gland [10]. In the brain, there also occurs the sub-type CB1A receptors [11]. The structure of CB2 receptor is similar to that of CB1 receptor (constructed of 360 amino acids and 7 transmembrane domains). These receptors are located on haematopoietic cells, keratocytes, the immune system, NK cells (Natural Killers), B lymphocytes, T lymphocytes, monocytes, macrophages, mast cells, and in the spleen and tonsils [12,13,14]. Onaivi [15] has reported the discovery and functional presence of CB2 cannabinoid receptors in the mammalian brain that may be involved in depression and drug abuse [15]. The stimulation of CB2 receptors leads to a decrease in the sensation of pain and alleviation of inflammatory states. Compounds which show affinity to CB1 and CB2 receptors may be classified into natural cannabinoids present in extracts from Cannabis, synthetic cannabinoids, and endocannabinoids, which are synthesised in the body of mammals. Considering their structure, CB1 and CB2 receptors show 44\% homology [16]. There is evidence indicating the presence of the cannabinoid CBx receptor in the brain [17].

\section{Analgesic effect}

The cannabinoid system plays an essential role in the process of antinociception (blocking pain sensation). Cannabinoids reduce acute and chronic pain of various aetiology (post-operative, cancer, migraine, neuropathic, rheumatic). The main problem is their psychotropic action. Therefore, the perspective to use selective CB2 receptor agonists is promising, which also have analgesic effect and, at the same time, are free from central undesirable effects [18]. It was observed that the mixture of THC and CBD has the capability of blocking platelet release of serotonin which occurs in the attacks of migraine [19]. In the treatment of neuropathic pain, a better effect was observed for the mixture of THC and CBD, than for the THC alone [20]. The applied mixture was well tolerated and also effective in reducing difficulty in falling asleep [21].

\section{Regulation of food intake}

The effect of cannabinoids in the treatment of obesity, anorexia and inhibition of vomiting is associated with antagonism of cannabinoid CB1 receptor, which is ascribed to participation in the possibility of controlling the satiety centre in the hypothalamus, regulation of metabolism and, in consequence, body weight control $[22,23]$. Probably, the cannabinoid system controls two types of food intake. In the limbic system, there exists a 
regulation of intake of tasty food, which is a source of pleasure. In the hypothalamus, the regulation of appetite 'on demand' is a direct response to short-term starvation. Leptin decreases the activity of the cannabinoid system in the hypothalamus. An increase in the concentration of anandamide in the hypothalamus was observed in animals with the defect of leptin receptor. Leptin applied in genetically obese mice caused a decrease in the concentration of endocannabinoids in the hypothalamus [24]. This confirms the relationship between the activity of leptin and the endocannabinoid system [25]. The cannabinoid system creates the orexigenic path, which is probably an alternative to the classical path, controlled via the neuropeptide Y. This may explain the increase in appetite, especially for sweets, observed in hashish and marijuana smokers. The cannabinoid path, similar to the classical, remains under the negative control of leptin [18]. In the regulation of appetite, the main role is ascribed to CB1 receptors present in large numbers in the hypothalamic regions controlling the process of food intake: in the lateral hypothalamus, para-ventricular nucleus, and arcuate nucleus. Their expression was observed on the crucial for this process peptidergic neurons that secrete corticotropin releasing hormone (CRH) in para-ventricular nucleus, and melanin-concentrating hormone (MCH) [26]. A high density of CB1 receptors was additionally observed in the mesolimbic system, which also regulates appetite, participating in the motivational processes and processes of behavioural activation in response to the rewarding agents. This is probably the key point of capture because many data show that cannabinoids increase appetite by enhancing the positively strengthening (rewarding) effect of food. This effect results from the intensification of dopaminergic transmission in the mesolimbic system and may be partly conditioned by interaction with the opioid system [27]. The possibility of an intensification of hedonistic response caused by food is supported by the observation that products activating endocannabinoids, e.g. chocolate, are known for their rewarding properties [28]. Since the beginning of the 1970s, many clinical studies have been conducted concerning the use of cannabis and CB1 receptor agonists in the state of decreased appetite. The result of these studies is the indication for the use of Dronabinol ${ }^{\circledR}$ and nabilone (Cesamet ${ }^{\circledR}$ ) in the treatment of anorexia in patients with cancer or AIDS [29]. Apart from the effect on the hedonist aspect of eating, they have anti-vomiting action and regulate the motility of the gastrointestinal tract. In patients with cancer, while applying chemotherapy and the treatment of cachexia syndrome in the course of AIDS, these properties have become a basis for the administration of dronabinol, and its synthetic derivative - nabilone [30].

At present, the possibility for using compounds blocking the CB1 receptor in the treatment of obesity evokes much hope. In various experimental models, including animals with genetically conditioned obesity, and obesity caused by high-caloric diet (i.e., diet-induced obesity), an anorectic effect of selective CB1 receptor antagonist SR141716A (Rimonabant ${ }^{\circledR}$ ) was confirmed. Thus, the central action of cannabinoids seems to be the most frequent cause of obesity in humans. In rats and mice on diet-induced obesity, SR 141716A also corrected the concomitant hyperglycaemia, decreased insulin resistance, reduced the level of plasma insulin, and normalised lipid profile [31]. In 2001, Sanofi-Synthelabo presented the results of phase II clinical studies evaluating rimonabant. A considerable decrease was noted in the feeling of hunger, food intake, and body weight, with no effect on the sense of taste. The reduction of body weight did not achieve a plateau during 4-month administration, and the preparation was well tolerated. At present, rimonabant is at phase III clinical studies including also obese patients with concomitant diseases, such as type 2 diabetes and dyslipidaemia [32].

\section{Mental disorders}

Mood swings are clearly visible in hashish and marijuana smokers, THC produces euphoria, but there also occur the states of dysphoria, which may be accompanied by fear, or even panic attacks. Sometimes, a clear anxiolytic effect is observed. It is considered that the direction of mood swing depends on wellbeing at the moment of intake of THC, dose, and route of administration. Studies on animals confirm the engagement of the cannabinoid system in the control of emotional states. In mice, an enhancement of fear, aggression and anhedonia are observed. Paradoxically, CB1 receptor antagonist SR141716A exerts an anxiolytic effect, which may suggest the presence of another receptor controlling the fear response [33]. It is also probable that the antagonistic effect results from mechanisms which are independent of the cannabinoid system.

The CB1 receptors are present in many brain structures responsible for perception and expression of emotions: in the amygdala, septum, hippocampus, frontal and prefrontal cortex [34]. The result of their stimulation are changes in the concentrations of transmitters related in an antagonistic way with fear reaction. Cannabinoids inhibit the release of glutamic acid, which is a stimulating amino acid in the hippocampus, as well as in the amygdala [33]. However, on the other hand, cannabinoids produce effects which may induce fear: reduce the activity of GABAergic neurons in the amygdala and hippocampus, which leads to the disinhibition of glutamatergic and dopaminergic transmission in the frontal cortex and the amygdala, and also stimulate the hypothalamic-pituitary-adrenal axis responsible for neuroendocrine response in conditions of emotional stress 
[35]. Based on these premises, in the group of CB1 receptor antagonists, potential neuroleptic drugs may be sought. The confirmation of this hypothesis is the anti-psychotic effect of cannabidiol [36].

CBD shows a wide range of therapeutic effects, including anxiolytic, anti-depressive and neuroprotective, within a wide scope of mental and neurodegenerative disorders [37,38]. Studies conducted based on neuroimaging showed that CBD affects the regions of the brain engaged in the neurobiology of psychiatric disorders [39].

Pre-clinical and clinical studies indicate that CBD is also potentially important in schizophrenia. CBD attenuates behavioural disorders related to schizophrenia [40,41]. Its effect is similar to that of atypical antipsychotic drugs [42]. In humans, anti-psychotic properties of CBD were confirmed by the method of a doubleblind clinical trial, where CBD reduced psychotic symptoms with effectiveness similar to that of an atypical anti-psychotic drug - amisulpride; however, with a considerably smaller number of side-effects [6]. Cannabidiol (CBD) has a wide range of beneficial effects in mental disorders [43]. CBD may modulate euphoric effects after taking THC, has a neuroprotective, anxiolytic effect, supporting the treatment of addiction to alcohol and nicotine [44]. Cannabidiol has anti-psychotic properties. Studies on animals [45] showed that CBD has a pharmacological profile similar to that of atypical anti-psychotic drugs. This includes neurochemical action and an effect on the patient's behaviour. Examinations performed using magnetic resonance imaging indicated that the effect of this compound takes place in the area of the striatum and temporal cortex. However, the mechanism of action has not been fully recognised. In 2014, it was confirmed that CBD exerts also a beneficial effect in the states of anxiety and depression [46]. The application of cannabinoids in bipolar disease caused the limitation in patients of the episodes of depression and persecution mania [47].

Neuroprotection is an essential mechanism of the effect of psychiatric drugs, protecting the structure and function of the nerve cells, promoting and protecting against oxidative stress, or an inflammatory process [48].

\section{Motor disorders, spasticity}

Natural and synthetic cannabinoids have a clear effect on motor functions. In small doses, they produce stimulation, whereas in high doses - motor depression or even catalepsy. This is conditioned by a high density of CB1 receptors in the cerebral cortex and the cerebellum, where the superior motor structures are located, and in the basal ganglia which are very significant in the processes of activation of voluntary movements, as well as in the mechanisms of maintaining skeletal muscle tone. Cannabinoids interfere in glutamatergic, GABAergic and dopaminergic neuronal paths, which may have important consequences for the therapy of Parkinson's disease, Huntington's disease, Tourette's syndrome, dystonia and spasticity occurring in multiple sclerosis (MS) and spinal cord injury [27,49].

The effect of cannabinoids has been best examined in multiple sclerosis. THC and nabilone result in the regression or alleviation of spasticity, night pain in legs, tremors, nycturia, paraesthesia, equilibrium disorders and memory. In the experimental MS model on animals, both CB1 and CB2 receptor agonists show a therapeutic effect, while their effect is eliminated by the selective antagonists of these receptors. In an experimental model of MS in mice, an increase in the concentration of AEA and 2-AG was observed in the brain and spinal cord, and elimination of spasticity under the effect of reuptake inhibitor. In turn, CB1 receptor antagonist enhances pathological symptoms. This may suggest that an increase in the concentration of endocannabinoids is the compensatory mechanism, activated in the course of MS [50]. Alleviation of spasticity may be explained by intensification of GABAergic transmission resulting from the inhibition of glutamate release [49].

The potential of cannabinoids in the treatment of Parkinson's disease is attributed to their neuroprotective effect against 6-hydroxydopamine, which has been confirmed in studies in vitro and in vivo [51]. CB receptors antagonists and agonists are said to effect the change in the symptoms of Parkinsonism, such as levodopainduced dyskinesia, and the reduction of dystonia. The role of cannabinoids in the treatment of Huntington's disease is associated with the agonist effect of cannabinoid compounds on CB1 receptors leading to the reduction of hyperactivity [52]. In patients with Tourette's syndrome, after the administration of THC, the reduction of ticks was observed, without causing acute and long-lasting cognitive deficits [53].

\section{Epilepsy}

The history of the use of cannabis for therapeutic and industrial purposes goes back to $2000 \mathrm{BC}$. In 1851, in the United States Pharmacopeia marijuana was classified as a legal medical agent, and many physicians supported its use in the treatment of epilepsy, chronic migraine and pain [54]. Reports by neurologists of the Victorian Epoch concerning the use of cannabis in the treatment of epilepsy were promising [55]. However, when phenobarbital and phenytoin were introduced to the market, the use of products based on marijuana decreased [56]. 
Epilepsy is a disease difficult to treat and, in this case, the drug containing cannabidiol has already started to be applied. In the United States, Epidiolex ${ }^{\circledR}$ containing CBD was developed which has the status of an orphan drug. Studies conducted in both adults and children indicate that CBD may improve the state of health and life comfort of patients with epilepsy [57]. It is postulated that the mechanism of action is related to the inhibition of glutamate release. The regulation of glutamatergic transmission may decrease the excitability of neurons, and consequently, reduce the frequency of seizure episodes. At the present stage of studies, it seems that a drug containing cannabidiol is a safe one. Studies of cannabinoids are a step towards the replacement of drugs with strong undesirable effects with drugs with a wide range of safe use [58].

According to up-to-date data, there are 65 million people suffering from epilepsy worldwide, and the incidence is 20-70 new cases per 10,000 population. The frequency of occurrence of epilepsy in children is $41-$ 187/100,000 [59]. In 30\% of patients, epilepsy remains drug-resistant despite the adequate pharmacological treatment applied. The first information in the media concerning the treatment with cannabinoids of children with Dravet syndrome occurred in 2013. A girl, Charlotte Figi, was administered a special oil (containing a high amount of CBD and low of THC, i.e. ratio 16:1) produced from the cannabis strain named Charlott's web [60]. Experimental studies indicate the possible anti-epileptic effect of cannabinoids, especially CBD. While evaluating the effectiveness of treatment with CBD, in the clinical studies, attention is usually paid to the reduction of the number of seizures easy to document, such as tonic seizures, atonic, and tonic-clonic seizures. The group of patients participating in double-blind, placebo-controlled trials covered a total of 48 patients, including 29 , who received CBD. The dose of CBD was 200-300 mg/daily [61-64]. Except for one study, in which 2 out of 4 patients were free from seizures, in the remaining cases no satisfactory effects of treatment with CBD as addon therapy were observed, and no significant differences were noted compared to the group of patients who received placebo [61,64]. The most frequently reported undesirable symptoms included: fatigue and sleepiness; diarrhoea and eating disorders. In a prospective clinical study, 9 out of 23 patients experienced more than $50 \%$ reduction in the frequency of seizures [65]. The mean reduction in the number of seizures was $32 \%$ at the dose of Epidiolex of $25 \mathrm{mg} / \mathrm{kg} /$ daily [65]. Moreover, Geffrey et al. [66] in 13 patients with drug-resistant epilepsy evaluated the effect of simultaneous administration of CBD and an antiepileptic drug - clobazam. A decrease in the concentration of CBD was an indication for decreasing the dose of clobazam. As a result of the administration of CBD, a $50-55 \%$ reduction of seizures was observed in $11 / 13$ patients, while in $2 / 13$ - an increased number of seizures [66]. Based on the results of studies, the use of CBD seems to be mainly valuable in the treatment of drug-resistant epilepsy in children [67]. In a retrospective study of 75 children and adolescents with epilepsy, who were administered extracts from cannabis, $57 \%$ of parents observed some improvement in the frequency of seizures by $33 \%-50 \%$. The parents have also noted an increase in the child's motility and behaviour; however, undesirable effects occurred such as sleepiness (12\%) and gastrointestinal disorders (11\%) [68].

\section{Conclusions}

Cannabinoids, mainly of plant origin (phytocannabinoids), seems to be very interesting biologically active compounds with many potential therapeutic properties. They are characterised by high safety considering the toxicity of compounds, while undesirable effects remain within the adopted standards. Studies concerning the therapeutic effect of cannabinoids are more common than at any time previously in history. There is an increasing number of studies indicating that the cannabis plant or single cannabinoids may have therapeutic properties for selected neurological diseases in specified conditions.

\section{Conflict of interests}

The authors state that there is no conflict of interests.

\section{References:}

1. Leite CE, Mocelin CA, Petersen GO, Leal MB, Thiesen FV. Rimonabant: an antagonist drug of the endocannabinoid system for the treatment of obesity. Pharmacol Rep. 2009; 61:217-24.

2. Hussain SA, Zhou R, Jacobson C, Weng J, Cheng E, Lay J, Hung P, Lerner JT, Sankar R. Perceived efficacy of cannabidiol-enriches cannabis extracts for treatment of pediatric epilepsy: A potential role for infantile spasms and Lennox-Gastaut sundrome. Epilepsy Behav. 2015; 47:138-41.

https://doi.org/10.1016/j.yebeh.2015.04.009 
3. Harvey DJ. Absorption, Distribution, and Biotransformation of the Cannabinoids. In: Nahas GG, Sutin KM, Harvey D, Agurell S, Pace N, Cancro R., editors. Marihuana and Medicine. Humana Press, Totowa, NJ; 1999. https://doi.org/10.1007/978-1-59259-710-9-10

4. Martin-Santos R, Crippa JA, Batalla A, Bhattacharyya S, Atakan Z, Borgwardt S, et al. Acute effects of a single, oral dose of d9-tetrahydrocannabinol (THC) and cannabidiol (CBD) administration in healthy volunteers. Curr Pharm Des. 2012; 18: 4966-79. https://doi.org/10.2174/138161212802884780

5. Hurd YL, Yoon M, Manini AF, Hernandez S, Olmedo R, Ostman M, et al. Early phase in the development of cannabidiol as a treatment for addiction: opioid relapse takes initial center stage. Neurotherapeutics. 2015; 12(4): 807-15. https://doi.org/10.1007/s13311-015-0373-7

6. Leweke FM, Piomelli D, Pahlisch F, Muhl D, Gerth CW, Hoyer C, et al. Cannabidiol enhances anandamide signaling and alleviates psychotic symptoms of schizophrenia. Transl Psychiatry. 2012; 2: e94. https://doi.org/10.1038/tp.2012.15

7. Glass M, Felder C. Concurrent simulation of cannabinoid CB1 and dopamine D2 receptor augments Camp accumulation in striatal neurons: evidence for a Gs linkage to the CB1 receptor. J Neurosci. 1997; 17(4): 5327-33.

8. Devane W, Hanus L, Breuer A, Pertwee R, Stevenson L, Griffin G, et al. Isolation and structure of a brain constituent that binds to the cannabinoid receptor. Scien. 1992; 258: 1946-9. https://doi.org/10.1126/science.1470919

9. Pertwee R. Evidence for the presence of CB1 cannabinoid receptor on peripheral neurons and for the existence of neuronal non-CB1 cannabinoid receptor. Life Sci. 1999; 65: 597-605.

10. Perrot S. Cannabis: the analgesic and anti-inflammatory medication of the future? Joint Bone Spine. 2004; 71: 7-8. https://doi.org/10.1016/j.jbspin.2003.10.006

11. Rutkowska M, Jamontt J. The role of cannabinoid system in the physiology and the pathophysiology of the central nervous system. Adv Clin Exp Med. 2005; 14(6): 1243-52.

12. Brooks JW. Cannabinoids and analgesia. Curr Anaesth Crit Care. 2002; 13: 215-20. https://doi.org/10.1054/cacc.2002.0406

13. Griffin G, Fernando S, Ross R, McKay N, Ashford M, Shire D, et al. Evidence for the presence of CB2-like cannabinoid receptors on peripheral nerve terminals. Eur J Pharmacol. 1997; 339:53-61. https://doi.org/10.1016/S0014-2999(97)01336-8

14. Munro S, Thomas K, Abu-Shaar M. Molecular characterization of a peripheral receptor for cannabinoids. Nature. 1993; 365: 61-5. https://doi.org/10.1038/365061a0

15. Onaivi ES. Neuropsychobiological evidence for the functional presence and expression of cannabinoid CB2 receptors in the brain. Neuropsychobiology. 2006; 54(4): 231-46. https://doi.org/10.1159/000100778

16. Childers SR, Breivogel CS. Cannabis and endogennous cannabinoid systems. Drug Alcohol Depend. 1998; 51: 173-87. https://doi.org/10.1016/S0376-8716(98)00075-1

17. Breivogel CS, Griffin G, Di Marzo V, Martin B R. Evidence for a new G protein-coupled cannabinoid receptor in mouse brain. Mol Pharmacol. 2001; 60: 155-63. https://doi.org/10.1124/mol.60.1.155

18. Iversen L, Chapman V. Cannabinoids: a real prospect for pain relief? Curr Opin Pharmacol. 2002; 2: 50-5.

19. Volfe Z, Dvilansky A, Nathan I. Cannabinoids block release of serotonin from plates induced by plasma from migraine patients. Int J Clin Pharmacol Res. 1985; 8: 243-6.

20. Russo E, Guy G. A tale of two cannabinoids: the therapeutic rationale for combining tetrahydrocannabinol and canabidiol. Med Hypotheses. 2006; 66: 234-46. https://doi.org/10.1016/j.mehy.2005.08.026

21. Rog D, Nurmikko T, Friede T, Young C. Randomized, controlled trial of cannabis-based medicine in central pain in multiple sclerosis. Neurology. 2005; 65(6): 812-9. https://doi.org/10.1212/01.wnl.0000176753.45410.8b

22. Beal J, Olson R, Lefkowitz L. Long-term efficacy and safety of dronabinol for acquired immunodefi ciency syndrome-associated anorexia. J Pain Symptom Manage. 1997; 14: 7-14. https://doi.org/10.1016/S0885-3924(97)00038-9

23. Randall MD, Kendall DA, Bennett AJ, O'Sullivan SE. Rimonabant in obese patients with type 2 diabetes. Lancet. 2007; 369(9561): 555. https://doi.org/10.1016/S0140-6736(07)60265-7

24. Di Marzo V, Goparaju SK, Wang L, Liu J, Bátkai S, Járai Z, et al. Leptin-regulated endocannabinoids are involved in maintaining food intake. Nature. 2001; 410: 822-5. https://doi.org/10.1038/35071088

25. Mechoulam R, Carlini E A. Toward drugs derived from cannabis. Naturwissenschaften. 1978; 65: 174-9.

26. Cota D, Marscicano G, Tschöp M, Grübler Y, Flachskamm C, Schubert M, et al. The endogenous cannabinoid system affects energy balance via central orexigenic drive and peripheral lipogenesis. J Clin Invest. 2003; 112: 423-31. https://doi.org/10.1172/JCI200317725 
27. Van der Stelt M, Di Marzo V. The endocannabinoid system in the basal ganglia and in the mesolimbic reward system: implications for neurological and psychiatric disorders. Eur J Pharmacol. 2003; 480: 133-50. https://doi.org/10.1016/j.ejphar.2003.08.101

28. Bruinsma K, Taren DL. Chocolate: food or drug? J Am Diet Assoc. 1999; 99: 1249-56. https://doi.org/10.1016/S0002-8223(99)00307-7

29. Robson P. Therapeutic aspects of cannabis and cannabinoids. Br J Psychiatry. 2001; 178: 107-15. https://doi.org/10.1192/bjp.178.2.107

30. Struwe M, Kaempfer SH, Geiger CJ, Pavia AT, Plasse TF, Shepard KV, et al. Effects of dronabinol on nutritional status in HIV infection. An Pharmacother. 1993; 27: 827-31. https://doi.org/10.1177/106002809302700701

31. Ravinet Trillou C, Arnone M, Delgore C, Gonalons N, Keane P, Maffrand JP, et al. Anti-obesity effect of SR 141716, a CB1 receptor antagonist, in diet - induced obese mice. Am J Physiol Regul Integr Comp Physiol. 2003; 284: 345-53. https://doi.org/10.1152/ajpregu.00545.2002

32. Fernandez JR, Allison DB. Rimonabant Sanofi-Synthelabo. Curr Opin Investig Drugs. 2004; 5: 430-5.

33. Martin M, Ledent C, Parmentier M, Maldonado R, Valverde O. Involvement of CB1 cannabinoid receptors in emotional behaviour. Psychopharmacology. 2002; 159: 379-87. https://doi.org/10.1007/s00213-001-0946-5

34. Millan MJ. The neurobiology and control of anxious states. Prog Neurobiol. 2003; 70: 83-244. https://doi.org/10.1016/S0301-0082(03)00087-X

35. De Miguel R, Hernandez-Tristan R. Cannabinoid effects on anxiety - related behaviours and hypothalamic neurotransmitters. Pharmacol Biochem Behav. 2001; 70: 123-31. https://doi.org/10.1016/S0091-3057(01)00578-0

36. Williamson EM, Evans FJ. Cannabinoids in clinical practice. Drugs. 2000; 60: 1303-14.

37. Campos AC, Fogaca MV, Sonego AB, Guimarães FS. Cannabidiol, neuroprotection and neuropsychiatric disorders. Pharmacol. Res. 2016; 112: 119-27. https://doi.org/10.1016/j.phrs.2016.01.033

38. Ligresti A, De Petrocellis L, Di Marzo V. From phytocannabinoids to cannabinoid receptors and endocannabinoids: pleiotropic physiological and pathological roles through complex pharmacology. Physiol Rev. 2016; 96: 1593-659. https://doi.org/10.1152/physrev.00002.2016

39. Crippa JA, Zuardi AW, Garrido GE, Wichert-Ana L, Guarnieri R, Ferrari L, et al. Effects of cannabidiol (CBD) on regional cerebral blood flow. Neuropsychopharmacology. 2004; 29: 417-26. https://doi.org/10.1038/sj.npp.1300340

40. Pedrazzi JF, Issy AC, Gomes FV, Guimarães FS, Del-Bel EA. Cannabidiol effects in the prepulse inhibition disruption induced by amphetamine. Psychopharmacology (Berl). 2015; 232:3057-65. https://doi.org/10.1007/s00213-015-3945-7

41. Renard J, Loureiro M, Rosen LG, Zunder J, de Oliveira C, Schmid S, et al. Cannabidiol counteracts amphetamineinduced neuronal and behavioral sensitization of the mesolimbic dopamine pathway through a novel mTOR/ p70S6 Kinase Signaling Pathway. J. Neurosci. 2016; 36: 5160-9. https://doi.org/10.1523/JNEUROSCI.3387-15.2016

42. Guimarães VM, Zuardi AW, Del Bel EA, Guimarães FS. Cannabidiol increases Fos expression in the nucleus accumbens but not in the dorsal striatum. Life Sci. 2004; 75: 633-8. https://doi.org/10.1016/j.lfs.2004.01.015

43. Campos AC, Moreira FA, Gomes FV. Multiple mechanisms involved in the large-spectrum therapeutic potential of cannabidiol in psychiatric disorders. Philos Trans R Soc Lond B Biol Sci. 2012; 367(1607): 336478. https://doi.org/10.1098/rstb.2011.0389

44. Morgan CJ, Das RK, Joye A, Curran HV, Kamboj SK. Cannabidiol reduces cigarette consumption in tobacco smokers: preliminary findings.AddictBehav.2011; 38:2433-6.https://doi.org/10.1016/j.addbeh.2013.03.011

45. Zuardi AW, Crippa JA, Hallak JE, Bhattacharyya S, Atakan Z, Martin-Santos R, et al. A critical review of the antipsychotic effects of cannabidiol: 30 years of a translational investigation. Curr Pharm Des. 2012; 18(32): 5131-40. https://doi.org/10.2174/138161212802884681

46. Schier de Mello AR, de Oliveira Ribeiro PN, Coutinho S, Machado S, Arias-Carrión O, Crippa JA, et al. Antidepressant-Like and Anxiolytic-Like Effects of Cannabidiol: A Chemical Compound of Cannabis sativa. CNS Neurol Disord Drug Targets. 2014; 13(6): 953-60. https://doi.org/10.2174/1871527313666140612114838

47. Abboud R, Sanders H. Effect of oral administration of delta-tetrahydrocannabinol on airway mechanics in normal and athmatic subjects. Chest. 1976; 70: 480-5. https://doi.org/10.1378/chest.70.4.480

48. Filipović D, Todorović N, Bernardi RE, Gass P. Oxidative and nitrosative stress pathways in the brain of socially isolated adult male rats demonstrating depressive- and anxiety-like symptoms. Brain Struct. Funct. 2017; 222: 1-20. https://doi.org/10.1007/s00429-016-1218-9 
49. Ameri A. The effects of cannabinoids on the brain. Prog Neurobiol. 1999; 58: 315-48. https://doi.org/10.1016/S0301-0082(98)00087-2

50. Glass M. The role of the cannabinoids in neurodegenerative diseases. Prog Neuropsychopharmacol Biol Psychiat. 2001; 25: 743-65. https://doi.org/10.1016/S0278-5846(01)00162-2

51. Lastres-Becker I, Molina-Holgado F, Ramos J, Mechoulam R, Fernandez-Ruiz J. Cannabinoids provide neuroprotection against 6-hydroxydopamine toxicity in vivo and in vitro: relevance to Parkinson's disease. Neurobiol Dis. 2005; 19: 96-107. https://doi.org/10.1016/j.nbd.2004.11.009

52. Lastres-Becker L, De Miguel R, De Petrocellis L, Makriyannis A, Di Marzo V, Fernandez-Ruiz J. Compounds acting at the endocannabinoid and/or endovanilloid system reduce hyperkinesia in a rat model of Huntington's disease. J Neurochem. 2003; 84: 1097-109. https://doi.org/10.1046/j.1471-4159.2003.01595.x

53. Muller-Vahl K, Prevedel H, Th eloe K, Kolbe H, Emrich H, Schneider U. Treatment of Tourette syndrome with delta-9-tetrahydrocannabinol (delta 9-THC): no influence on neuropsychological performance. Neuropsychopharmacology. 2003; 28: 384-8. https://doi.org/10.1038/sj.npp.1300047

54. Baron EP. Comprehensive review of medicinal marijuana, cannabinoids, and therapeutic implications in medicine and headache: what a long strange trip it's been... . Headache. 2015; 55(6): 885- 916. https://doi.org/10.1111/head.12570

55. Friedman D, Devinsky O. Cannabinoids in the treatment of epilepsy. N Engl J Med. 2015; 373(11): $1048-58$. https://doi.org/10.1056/NEJMra1407304

56. Campbell CT, Phillips MS, Manasco K. Cannabinoids in Pediatrics. J Pediatr Pharmacol Ther. 2017; 22(3): 17685. https://doi.org/10.5863/1551-6776-22.3.176

57. Szaflarski JP, Bebin EM. Cannabis, cannabidiol, and epilepsy-from receptors to clinical response. Epilepsy Behav. 2014; 41:277-82. https://doi.org/10.1016/j.yebeh.2014.08.135

58. Santos RG, Hallak JEC, Leite JP, Zuardi AW, Crippa JA. Phytocannabinoids and epilepsy. J Clin Pharm Ther. 2014; 40(2): 135-43. https://doi.org/10.1111/jcpt.12235

59. Camfield P, Camfield C. Incidence, prevalence and aetiology of seizures and epilepsy in children. Epileptic Disord. 2015; 17: 117-23. https://doi.org/10.1684/epd.2015.0736

60. Maa E, Figi P. The case for medical marijuana in epilepsy. Epilepsia. 2014; 55:783-6. https://doi.org/10.1111/epi.12610

61. Ames FR, Cridland S. Anticonvulsant effect of cannabidiol. S Afr Med J. 1985; 69(1): 14.

62. Cunha JM, Carlini EA, Pereira AE, Ramos OL, Pimentel C, Gagliardi R, et al. Chronic administration of cannabidiol to healthy volunteers and epileptic patients. Pharmacology 1980; 21: 175-85.

63. Mechoulam R, Fride E. A hunger for cannabinoids. Nature. 2001; 410: 763-5. 10.1038/35071214

64. Welty TE, Luebke A, Gidal BE. Cannabidiol: promise and pitfalls. Epilepsy Curr. 2014; 14(5): $250-2$. https://doi.org/10.5698/1535-7597-14.5.250

65. Devinsky O, Cilio MR, Cross H, Fernandez-Ruiz J, French J, Hill C, Katz R, Di Marzo V, Jutras-Aswad D, Notcutt WG, Martinez-Orgado J, Robson PJ, Rohrback BG, Thiele E, Whalley B, Friedman D. Cannabidiol: Pharmacology and potential therapeutic role in epilepsy and other neuropsychiatric disorders. Epilepsia. 2014; 55:791802. https://doi.org/10.1111/epi.12631

66. Geffrey AL, Pollack SF, Bruno PL, Thiele EA. Drug-drug interaction between clobazam and cannabidiol in children with refractory epilepsy. Epilepsia. 2015; 56: 1246-51. https://doi.org/10.1111/epi.13060

67. Consroe P, Martin A, Singh V. Antiepileptic potential of cannabidiol analogs. J Clin Pharmacol. 1981; 21:428S-36S. https://doi.org/10.1002/j.1552-4604.1981.tb02623.x

68. Press CA, Knupp KG, Chapman KE. Parental reporting of response to oral cannabis for treatment of refractory epilepsy. Epilepsy Behav. 2015; 45:49-52. https://doi.org/10.1016/j.yebeh.2015.02.043 